Matjaž Vesel*

\title{
Newton, nedosegljivo bistvo teles, teološki voluntarizem in zakoni narave'
}

Znamenita "Splošna sholija $",{ }^{2}$ ki zaključuje drugo in tretjo izdajo Newtonovih Matematičnih principov filozofije narave, je bila - in je še vedno - predmet posebnega zanimanja in preučevanja zaradi več razlogov. Newton v njej med drugim zapiše razvpito trditev »Hipotez si ne izmišljam « (Hypotheses non fingo), ${ }^{3}$ predvsem pa v njej pojasnjuje, kako razume Boga in njegovo prisotnost v naravi ter posledično v filozofiji narave. Svoje razmišljanje sklene $\mathrm{z}$ ugotovitvijo, da »razpravljanje o Bogu iz pojavov vsekakor spada na področje filozofije narave«, ${ }^{4}$ v tem okviru pa tudi zatrdi, da smo ljudje, kar zadeva Boga, omejeni na spoznanje njegovih atributov, kar zadeva spoznanje teles, pa na njihove pojave:

Imamo ideje o njegovih atributih, toda sploh ne spoznavamo, kaj je substanca katere koli stvari. Vidimo samo oblike in barve teles, slišimo samo <njihove $>$ zvoke, dotikamo se samo <njihovih $>$ zunanjih površin, vohamo samo <njihove $>$ vonje in okušamo <njihove> okuse; <njihovih> najglobljih substanc pa ne spoznavamo z nobenim čutom, z nobeno premišljujočo dejavnostjo in še dosti manj imamo idejo o substanci Boga. ${ }^{5}$

1 Prispevek je nastal v okviru raziskovalnega programa P6-0014 »Pogoji in problemi sodobne filozofije« in projekta J6-9392 »Problem objektivnosti in fikcije v sodobni filozofiji«, ki ju financira Javna agencija za raziskovalno dejavnost Republike Slovenije.

2 Za original gl. Isaac Newton, Philosophiae Naturalis Principia Mathematica, ur. Alexandre Koyré in I. Bernard Cohen s pomočjo Anne Whitman, tretja izdaja Principia iz leta $1726 \mathrm{z}$ različicami besedila iz prvih dveh izdaj, dva zvezka s kontinuirano paginacijo, Harvard University Press, Cambridge 1972, str. 759-765. Slovenski prevod Principov navajam po: Isaac Newton, Matematični principi filozofije narave: kratek izbor, prev. Matej Hriberšek, pričujoča številka Filozofskega vestnika 41 (3/2020), str. 9-79; »Splošna sholija«, str. 73-79. V nadaljevanju se na besedilo včasih sklicujem kot na Principia ali Principi.

3 Ibid., str. 764; slov. prev. str. 78. Cf. tudi uredniško opombo k prevodu »Splošne sholije«, tu, str. 74 .

4 Ibid., slov. prev. str. 78.

5 Ibid., str. 763; slov. prev. str. 77. 
Če pustimo »idejo o substanci Boga« ob strani in se osredotočimo na telesa, to $\mathrm{z}$ drugimi besedami pomeni, da so za nas njihove substance oz. bistva spoznavno nedostopna, ali - povedano še nekoliko drugače - da ni mogoče podati bistvene definicije teles, tj. definicije, ki bi zadevala njihovo bistvo ali substanco. ${ }^{6}$ Dejansko nobena od treh izdaj Principia ne vsebuje absolutne definicije telesa. Takšne opredelitve ni med začetnimi definicijami (»količina materije«, »količina gibanja«, »notranja sila« (vis insita), »vtisnjena sila« (vis impressa), »sredotežna sila« in njene tri mere: »absolutna«, »pospeševalna« in "gibalna«), niti v sholiji $\mathrm{k}$ tem definicijam, v kateri Newton pojasnjuje čas, prostor in gibanje ter ločuje med absolutnim in relativnim pomenom teh pojmov, niti v preostanku besedila, v katerem definira, denimo, tekočine. ${ }^{7}$

Vprašanje, ki se ob tem zastavlja samo od sebe, je seveda: zakaj je temu tako? Zakaj po Newtonu niti naše čutno-zaznavno spoznavanje teles niti nobena refleksivna, miselna dejavnost ne omogoča, da bi lahko prišli do spoznanja njihovega bistva oz. narave? Po eni strani je sicer razumljivo, da kot samooklicani eksperimentalni filozof zavrača možnost »racionalističnega«, zgolj miselnega spoznanja bistva teles à la Descartes, vendar pa je po drugi strani manj razumljivo, zakaj obenem zavrača spoznavanje bistva teles prek njihovih čutno-zaznavnih kvalitet ali lastnosti. Še enkrat: zakaj Newton zameji spoznanje teles na njihovo fenomenalno, pojavno raven?

6 O različnih vidikih Newtonove teoriji teles in povezanih vprašanjih obstaja kar nekaj literature. Cf. npr. Dana Jalobeanu, »Space, Bodies and Geometry: Some Sources of Newton's Metaphysics«, Zeitsprünge: Forschungen zur frühen Neuzeit 11 (1-2/2007), str. 81-113; ista, »The Nature of Body«, v Peter Anstey (ur.), The Oxford Handbook of British Philosophy in the Seventeenth Century, Oxford University Press, Oxford 2013, str. 213-239; Daniel Garber, John Henry, Lynn Joy in Alan Gabbey, »New Doctrines of Body and its Powers, Place and Space«, v Daniel Garber in Michael Ayers (ur.), The Cambridge History of Seventeenth Century Philosophy, 1. zv., Cambridge University Press, Cambridge 1998, str. 553-623; Dana Jalobeanu, »The Cartesians of the Royal Society: The Debate over Collisions and the Nature of Body (1668-1670)«, v Dana Jalobeanu in Peter Anstey (ur.), Vanishing Matter and the Laws of Nature: Descartes and Beyond, Routledge, London 2011, str. 103-129; Peter Damerow, "Space and Matter in Early Modern Science: The Impenetrability of Matter «, v Matthias Schemmel (ur.), Spatial Thinking and External Representation: Towards a Historical Epistemology of Space, Max Planck Institute for the History of Science, Berlin 2016, str. 175-190.

7 Cf. Principia, str. 417. 
$\mathrm{Z}$ namenom, da bi odgovoril na to vprašanje, bom v članku najprej na kratko orisal recepcijo prve izdaje Principov iz leta 1687, ki v določeni meri pojasnjuje Newtonove spremembe in dodatke iz druge izdaje iz leta 1713, vključno s prej citirano »Splošno sholijo«, in nato preletel še dve besedili iz te izdaje, v katerih so telesa obravnavana na podoben način kot v »Splošni sholiji«, tj. predgovor Rogerja Cotesa in »Pravila filozofiranja«, poleg tega pa še osnutke »Splošne sholije«. Med temi besedili so predvsem »Splošna sholija« skupaj z njenimi osnutki ter nekateri drugi rokopisi, ravno tako povezani s Principi, tisti, ki nakazujejo, v kateri smeri je treba iskati odgovor na naše vprašanje: to je Newtonov »totalitarni« teološki voluntarizem. ${ }^{8}$ Tega bom analiziral v tretjem in zadnjem kora$\mathrm{ku}$. Newton je teološki voluntarizem $\mathrm{v}$ izrecni navezavi na problematiko narave teles $\mathrm{v}$ polnosti prvič razvil $\mathrm{v}$ svojem mladostnem filozofskem obračunu $\mathrm{z}$ Descartesom v rokopisu »O težkosti« (De gravitatione), nekatere vidike, ki niso vedno izrecno navezani na teorijo telesa, pa lahko zasledimo tudi v nekaterih drugih besedilih. Newtonovo stališče do tega vprašanja bom na koncu osvetlil še s primerjavo z Descartesovim stališčem.

\section{Odzivi na prvo izdajo Principov ter popravki, spremembe in dopolnila druge izdaje}

Razlogov, da je Newton drugo izdajo Matematičnih principov filozofije narave zaključil s "Splošno sholijo« in besedilo na nekaterih mestih bistveno spremenil, je bilo več. ${ }^{9}$ Takoj po izidu leta 1687 so izšle štiri recenzije, ${ }^{10}$ med katerimi je bila tehnično najpodrobnejša tista, ki jo je za Acta eroditorum napisal profesor

8 Liam Dempsey, »Newtonian Idealism: Matter, Perception, and the Divine Will«, The Southern Journal of Philosophy 52 (1/2014), str. 93, op. 20, imenuje Newtonovo pojmovanje »a totalitarian conception of God's will«.

9 Cf. tudi uredniško opombo h kratkemu izboru besedil iz Matematičnih principov filozofije narave, tu, str. 9.

10 V letih 1688-89 so izšle štiri anonimne recenzije, katerih avtorji pa so danes znani. To so bili astronom in Newtonov znanec Edmond Halley, kartezijanski filozof Pierre Sylvain Régis, angleški filozof John Locke in profesor matematike na Univerzi v Leipzigu Christoph Pfautz. Cf. Bernard Cohen, »The Review of the First Edition of Newton's Principia in the Acta Eruditorum, with Notes on the other Reviews«, v P. M. Harman in Alan E. Shapiro (ur.), The Investigation of Difficult Things: Essays on Newton and the History of the Exact Sciences in Honour of D. T. Whiteside, Cambridge University Press, Cambridge 1992, str. 323-354. O tem, kaj sta si o knjigi mislila Gottfried Wilhelm Leibniz in Christiaan Huygens, cf. Alexandre Koyré, Newtonian Studies, Chapman in Hall, London 1965, str. 115-138. 
matematike na Univerzi v Leipzigu Christoph Pfautz. Pfautzu se je med drugim zdelo vredno parafrazirati nekaj stavkov iz tretje knjige, naslovljene »Sistem sveta«, v kateri Newton izračuna gostoto planetov Saturna, Jupitra in Zemlje ter razvije pravilo za razmerje njihovih gostot, potem pa sklene: »Bog je torej planete postavil na različne razdalje od Sonca, tako da lahko vsak od njih uživa večjo ali manjšo količino toplote Sonca glede na stopnjo svoje gostote. « ${ }^{11} \mathrm{~V}$ prvi izdaji Principia je to edina Newtonova omemba Boga in - implicitno - njegovega umnega, inteligentnega načrta pri stvarjenju našega osončja.

Mogoče je ravno to mesto spodbudilo preučevalca antike Richarda Bentleya, ki je imel v letih 1691/92 »govore« ali »pridige« (sermons) v okviru t. i. Boylovih predavanj, katerih osnovni namen je bila obramba krščanske vere pred nevarnostjo ateizma, ${ }^{12}$ da se je za pomoč obrnil na Newtona. ${ }^{13}$ Še posebej ga je zanimalo, kako Matematični principi filozofije narave osvetljujejo dejstvo, da je naš sončni sistem ustvaril umni dejavnik, tako da ta ni nastal kot naključni učinek slepih in samodejnih fizičnih interakcij materialnih teles, kot naj bi - takšno je bilo v tem obdobju v Angliji prevladujoče prepričanje - izhajalo iz različnih inačic mehanicistične filozofije, predvsem Descartesove, pa tudi Hobbesove. Newton mu je v štirih pismih odgovoril, da - rečeno zelo na kratko - po njegovem mnenju golo, slepo naključje ne bi moglo postaviti planetov ravno na prava mesta, da se ohrani stabilen sončni sistem. Za to je bil potreben "premislek in urejanje (contirevance) voljnega dejavnika ${ }^{14} \mathrm{Oz}$. »umni dejavnik« (intelligent agent). ${ }^{15}$

Newtona je k spremembam in dodatkom spodbudila tudi dolgotrajna, dvajset let trajajoča polemika z Leibnizem, ki je zadevala predvsem naravo gravitacije. Leibniz, ki je, tako kot pred njim že René Descartes in Christiaan Huygens, kot

${ }^{11}$ V originalu, Principia, str. 582-583, se stavek glasi: »Collocavit igitur Deus Planetas in diversis distantiis a Sole, ut quilibet pro gradu densitatis calore Solis majore vel minore fruatur."

12 Cf. Matjaž Vesel, »Newtonova zgodnja dela: narava svetlobe in barv, teorija materije in filozofski obračun z Descartesom«, v Isaac Newton, Izbrani spisi I, Založba ZRC, Ljubljana 2020, str. 182-185.

${ }_{13}$ Od Bentleyevih pisem se je ohranilo samo tretje, Newtonova pa so bila prvič objavljena šele leta 1756. Za ta cf. npr. Isaac Newton, Philosophical Writings, Cambridge University Press, Cambridge 2014, str. 119-139.

14 Ibid., str. 121.

15 Ibid., str. 126. 
mehanične vzroke gibanj planetov razumel nebesne vrtince materije, ${ }^{16}$ vzajemne privlačnosti splošne gravitacije enostavno ni mogel razumeti, saj naj bi ta vpeljevala delovanje na daljavo. $\mathrm{V}$ tej polemiki, $\mathrm{v}$ katero se je $\mathrm{z}$ svojim predgovorom k drugi izdaji vključil tudi Roger Cotes, so padale težke besede. Leibniz je Newtona obtožil, da je v filozofijo zopet vpeljal »okultne«, tj. skrite kvalitete, ki jih je mehanicistična filozofija odpravila, kar da nas »vodi nazaj v kraljestvo teme «, ${ }^{17}$ na drugi strani je Newtonov porte-parole Cotes teorijo vrtincev razglasil za neosnovano, »povsem nesmiselno in povsem nevredno filozofa «. ${ }^{18}$

Vse to - poleg želje popraviti nekatere tehnične napake prve izdaje in vključiti najnovejše astronomske ugotovitve - se je odrazilo v dodatkih in spremembah druge izdaje Matematičnih principov filozofije narave. Naj naštejem samo nekatere najbolj opazne. Prvi večji dodatek druge izdaje predstavlja proti-mehanicistični (tj. proti-kartezijanski in proti-leibnizovski) predgovor urednika Cotesa. Naslednja večja sprememba so znamenita »Pravila filozofiranja «, ${ }^{19}$ delo pa zaključuje - v primerjavi s preostalim besedilom - precej nenavadna "Splošna sholija«. V vseh omenjenih besedilih Newton razmišlja o telesih, njihovih lastnostih in omejenem dometu človeškega spoznanja na raven pojavnosti, tj. na njihovo čutno-zaznavno pojavnost, vendar pa v nobenem ta omejitev ni natančneje obrazložena.

Cotes v delu predgovora, v katerem argumentira proti kartezijanski teoriji vrtincev in polnemu vesolju, tj. vesolju, v katerem ni nobene praznine ali vakuuma, medtem ko upravičuje koncept težkosti oz. gravitacije, čisto na kratko povzame, kaj so po Newtonu lastnosti ali kvalitete teles in kako jih spoznamo:

Razsežnost teles, gibljivost in nepredirnost postanejo znane samo s poskusi; na povsem enak način postane znana težkost. Vsa telesa, ki so predmet naših opazovanj, so razsežna, gibljiva in nepredirna in od tod sklepamo, da so vsa telesa, tudi tista, ki niso predmet naših opazovanj, razsežna, gibljiva in nepredirna. Tako so vsa telesa, ki so predmet naših opazovanj, težka in od tod sklepamo, da so vsa telesa, tudi tista, ki niso predmet naših opazovanj, težka. Če bi kdo rekel, da

16 Vrtince kot vzroke gibanja planetov je zagovarjal tudi Descartes.

${ }_{17}$ Cf. Anti-barbarus physicus, v Gottfried W. Leibniz, Die philosophischen Schriften, 7. zv., ur.

C. I. Gerhardt, Berlin 1890, str. 337-344.

18 Cf. Principia, str. 32; slov. prev. str. 34.

19 Cf. uredniško opombo k »Pravilom filozofiranja«, tu, str. 68. 
telesa zvezd stalnic niso težka, ker njihova težkost še ni bila opažena, bo z isto utemeljitvijo mogoče reči, da niso ne razsežna ne gibljiva in ne nepredirna, ker te afekcije zvezd stalnic še niso bile opažene. Kaj bi še govoril? Med primarnimi kvalitetami vseh teles bo ali težkost imela svoj prostor ali pa ga razsežnost, gibljivost in nepredirnost ne bodo imele. In narava stvari bo ali pravilno razložena s težkostjo teles ali pa ne bo pravilno razložena $\mathrm{z}$ razsežnostjo, gibljivostjo in nepredirnostjo teles. ${ }^{20}$

V povzetku je po Cotesu za vsa telesa torej značilno, da imajo štiri primarne kvalitete. Vsa telesa so razsežna, gibljiva in nepredirna, poleg tega pa so tudi težka, saj so vsa telesa, ki jih lahko opazujemo taka. Na lastnosti ali kvalitete teles, ki jih ne moremo neposredno opazovati, moramo torej sklepati po analogiji s tistimi, ki jih lahko opazujemo oz. lahko na njih izvajamo preizkuse. Kar je pri tem $\mathrm{z}$ našega vidika zanimivo je predvsem dejstvo, da Cotes sploh ne omenja bistva teles, temveč ga pri telesih zanimajo samo njihove »zunanje« lastnosti.

Cotes tu pravzaprav povzema Newtonovo tretje pravilo filozofiranja, ki zadeva problem indukcije in ravno tako govori o kvalitetah oz. lastnostih teles. Newtonovo izhodišče je, da z zaznavami in poskusi v nam dostopnem vesolju spoznamo, da imajo stvari okoli nas določene lastnosti oz. kvalitete. Problem, ki se mu zastavlja, je, kako je s stvarmi, ki nam niso dostopne. Kako lahko pridemo do sklepov o predmetih in pojavih v preostalem, nam nedostopnem delu vesolja? Kako vemo, da ima Sonce določeno količino materije, tj. maso, da je materialno telo? Kako lahko vemo, da ima v osnovi enake lastnosti kot katerokoli drugo materialno telo, ki se ga lahko dotaknemo ali na njem izvajamo preizkuse? Na podlagi česa lahko Soncu pripišemo, da izvaja silo gravitacije? In še bolj splošno: kako lahko izpeljemo splošno gravitacijo, gravitacijo, ki velja tudi v nam nedostopnih predelih vesolja? ${ }^{21}$ Kot rešitev teh težav navaja tretje pravilo filozofiranja, ki se glasi:

Kvalitete teles je namreč mogoče ugotoviti samo s poskusi, in zato je treba postaviti kot splošne kvalitete vse tiste, ki se na splošno ujemajo s poskusi; in kvalitet, ki se ne morejo zmanjšati, <telesom> ni mogoče odvzeti. Seveda se proti utemelje-

20 Principia, str. 26-27; slov. prev. str. 28.

${ }_{21}$ Newton takšen sklep o nedostopnem delu vesolja izpelje v 7. propoziciji tretje knjige Principia, kjer pojasnjuje splošno gravitacijo. Cf. ibid., str. 576-577. 
nim argumentacijam na osnovi poskusov ne sme izmišljati nepremišljenih sanjarij, in tudi se ne sme odmakniti od analogije narave, ker je ta navadno enostavna in vedno skladna s sabo. ${ }^{22}$

Newton pravilo razlaga tako, da se delno opre na svoje zakone narave ali aksiome gibanja. ${ }^{23}$ Da so telesa razsežna, trda, nepredirna, gibljiva in da vztrajajo v gibanju ali mirovanju s pomočjo sil inercije, ne ugotavljamo na podlagi razuma, temveč s čuti. Ker razsežnost pripada vsem zaznavnim telesom, jo pripisujemo vsem telesom, ker zaznavamo trdnost v številnih čutno-zaznavnih telesih, to pripisujemo vsem. Isto velja za nepredirnost, gibanje in mirovanje ter silo inercije:

Razsežnost, trdost, nepredirnost, gibljivost in sila inercije celote izvira iz razsežnosti, trdosti, nepredirnosti, gibljivosti in sil inercije delov; in iz tega sklepamo, da so vsi najmanjši deli vseh teles razsežni, da so trdi, nepredirni, gibljivi in obdarjeni s silami inercije. In to je temelj vse filozofije narave. ${ }^{24}$

O razsežnosti, trdosti, nepredirnosti, gibljivosti in inercijskih silah teles sklepamo na podlagi pojavov, tega, kar vidimo, čutimo, zaznamo. Kar je razvidno na makro-ravni, je zelo verjetno prisotno tudi na mikro-ravni: telesca imajo iste primarne lastnosti kot makro telesa. Toda ali sodi v to kategorijo tudi gravitacija? Po Newtonu, da. Tudi težkost, težnost oz. gravitacija (gravitas) sodi v kategorijo primarnih lastnosti teles.

Končno: če je na osnovi poskusov in astronomskih opazovanj na splošno znano, da vsa telesa na Zemlji ali okoli nje težijo proti Zemlji in to sorazmerno s količino materije v posameznih <telesih>, da Luna teži proti Zemlji sorazmerno s količino svoje materije in da obrnjeno naše morje teži proti Luni, da vse premičnice vzajemno težijo ena proti drugi in da obstaja podobna težkost kometov proti Soncu, bo treba po tem <tretjem > pravilu reči, da vsa telesa vzajemno težijo eno proti drugemu. Utemeljitev glede splošne težkosti bo namreč na osnovi pojavov še močnejša kot utemeljitev glede nepredirnosti teles; zanjo pa v primeru nebesnih teles nimamo sploh nobenega poskusa in čisto nobenega opazovanja. ${ }^{25}$

\footnotetext{
22 Ibid. str. 552-553; slov. prev. str. 69-70.

${ }_{23}$ Cf. ibid., str. 54-72; slov. prev. str. 53.

24 Ibid., str. 554; slov. prev. str. 70.

25 Ibid., str. 554-555; slov. prev. str. 70.
} 
Ker zaznavamo, da vsa telesa, ki so blizu Zemlje ali na njej, gravitirajo proti Zemlji, in da Luna gravitira proti Zemlji itd., lahko sklepamo, da vsa telesa vsepovsod gravitirajo proti drugim telesom. Zdi se, da Newton trdi, da je gravitacija ki je zanj vtisnjena sila, dejavnost (actio) - nekaj takšnega, kot so kvalitete ali lastnosti razsežnosti in nepredirnosti. ${ }^{26}$

Cotes je torej dokaj verno povzel Newtonovo razmišljanje. Po Newtonu lahko o kvalitetah ali lastnostih teles sklepamo na podlagi pojavov, naš dostop do njih je omejen na fenomenalno raven. Vendar pa je Newton nekoliko bolj jasen kot Cotes. Izrecno namreč zatrdi, da gravitacija ne sodi k bistvu teles, kar z drugimi besedami pomeni, da pravzaprav ne vemo, kaj je narava oz. bistvo telesa. Zadnji stavek tretjega pravila se namreč glasi: »Kljub temu pa sploh ne zatrjujem, da je težkost bistvena za telesa. $^{27}$ Zopet smo pri izhodiščnem problemu. Zakaj kljub temu, da lahko določimo lastnosti teles, ne moremo spoznati tudi njihovega bistva?

Kot je razvidno iz odlomka, navedenega na začetku članka, zagovarja Newton isto stališče tudi v zadnjem večjem dopolnilu druge izdaje Principov, v »Splošni sholiji«, njegovi »zadnji besedi«, ponatisnjeni tudi v tretji izdaji Principov, ki je luč sveta zagledala leto pred njegovo smrtjo. Ko sem že opozoril, se je Bentley med pripravljanjem Boylovih predavanj na Newtona najverjetneje obrnil zaradi enega samega stavka iz prve izdaje Principia, ki ga je izpostavil tudi recenzent Pfautz: »Bog je torej planete postavil na različne razdalje od Sonca, tako da lahko vsak od njih uživa večjo ali manjšo količino toplote Sonca glede na stopnjo svoje gostote. $\ll^{28} \mathrm{~V}$ drugi izdaji ja ta stavek spremenjen tako, da Bog ni več omenjen - »Planeti so bili postavljeni na različnih razdalja od Sonca." - 29 in videti je, da je »Splošna sholija « namenjena širši pojasnitve tega, kar je imel Newton v mislih s stavkom iz prve izdaje. "Splošna sholija « namreč na oder Matematičnih principov filozofije narave postavi Boga in, med drugim, tudi analogijo med našim spoznavanjem Boga in spoznavanjem teles ter odvisnost raznolikosti ustvarjenih stvari od volje Boga.

26 Leibniz in drugi Newtonovi kritiki so se torej popolnoma legitimno spraševali ali je gravitacija skrita kvaliteta teles po vzoru sholastičnih skritih kvalitet.

${ }_{27}$ Ibid., str. 555; slov. prev. str. 70-71.

28 Ibid., str. 582-583.

29 Ibid. 
Newton, podobno kot v pismu Bentleyu, tudi v »Splošni sholiji« trdi, da je v Principih pojasnjena ureditev "Sonca, planetov in kometov [...] lahko nastala zgolj in samo po načrtu in gospostvu umnega in mogočnega Bitja.$^{30}$ Če so, spekulira Newton, »zvezde stalnice središča podobnih sistemov, bodo vsi ti sistemi zgrajeni po podobnem načrtu in podrejeni gospostvu Enega . $^{11}$ Bog »vlada vsem ne kot duša sveta, ampak kot gospodar vsega «.32 Bog je »večno, neskončno in absolutno popolno bitje; toda bitje, kakor koli že popolno, brez gospostva ni Gospod Bog.«33 Iz božjega gospodovanja sledi, »da je resnični Bog živ, umen in mogočen «. ${ }^{34}$ Iz ostalih božjih popolnosti pa sledi, da je najbolj popoln. Je večen in neskončen in »z obstajanjem vedno in povsod tvori trajanje in prostor«.35 Bog je

vseprisoten ne samo s svojo dejavno močjo, ampak tudi s substanco, kajti moč ne more samostojno obstajati brez substance. $\mathrm{V}$ njem samem so vsebovane in se gibljejo vse stvari, toda brez vzajemnega utrpevanja. Bog ne utrpeva ničesar od gibanj teles; ta telesa ne čutijo nobenega upora od vseprisotnosti Boga. ${ }^{36}$

Newtonov Bog nujno obstaja in je zaradi iste nujnosti vedno in povsod. Zato je tudi ves enak sebi. Sledi izjemno pomembna izpeljava, ki zadeva telesa in sem jo navedel že na začetku: tako kot smo pri Bogu omejeni na spoznanje njegovih atributov, smo pri spoznanju teles omejeni na njihove pojave, ne moremo pa spoznati njihove substance. Tole je nekoliko razširjen navedek:

Kakor slepec nima ideje o barvah, tako mi nimamo ideje o načinih, na katere najmodrejši Bog čuti in umeva vse. Nima nobenega telesa in prav nobene telesne oblike in zato ga ni mogoče videti ne slišati ne dotakniti se ga in ne častiti ga pod podobo kake telesne stvari. Imamo ideje o njegovih atributih, toda sploh ne spoznavamo, kaj je substanca katere koli stvari. Vidimo samo oblike in barve teles, slišimo samo <njihove> zvoke, dotikamo se samo <njihovih> zunanjih površin, vohamo samo <njihove > vonje in okušamo <njihove > okuse; <njihovih > najglobljih substanc pa ne spoznavamo z nobenim čutom, z nobeno premišljujočo de-

\footnotetext{
Ibid., str. 760; slov. prev. str. 76.

Ibid.

Ibid.

33 Ibid.

34 Ibid., str. 761; slov. prev. str. 76.

35 Ibid.

36 Ibid., str. 762; slov. prev. str. 77.
} 
javnostjo in še dosti manj imamo idejo o substanci Boga. Tega spoznavamo samo po njegovih lastnostih in atributih, po najmodrejših in najboljših ureditvah stvari in smotrnih vzrokih ter ga občudujemo zaradi popolnosti; spoštujemo in častimo pa ga zaradi gospostva. ${ }^{37}$

To misel je Newton mogoče še jasneje formuliral v več osnutkih »Splošne sholije«, med katerimi se mi zdi najbolj povedna različica iz »Osnutka C«. V njem Newton ponovi trditev, da vse, kar vemo o lastnostih teles, prihaja od pojavov, čemur doda opozorilo, da ne smemo prehitro zatrditi tistega, o čemer ni mogoče sklepati na podlagi pojavov:

Lastnosti stvari poznamo na podlagi pojavov in iz lastnosti izpeljemo, da stvari obstajajo in imenujemo jih substance; toda o substancah nimamo nobene ideje. Vidimo samo oblike in barve teles, slišimo zvoke, dotikamo se površin, vonjamo vonjave in zaznavamo okuse, toda substanc ali bistev samih ne zaznamo $\mathrm{z}$ nobenim čutom; z nobeno premišljujočo dejavnostjo, in torej o njih nimamo nič več ideje, kot jo ima slepec o barvah. Ko se reče, da imamo idejo Boga ali idejo telesa, to pomeni zgolj to, da imamo idejo o lastnostih ali atributih Boga ali idejo o lastnostih, s katerimi se telesa razlikujejo od Boga in med seboj. Od tod sledi, da nikjer ne argumentiram o idejah substanc, razen o njihovih lastnostih, in da iz tega ne izpeljem nobenih sklepov.38

Newton torej zopet zatrjuje, da ne moremo poznati narave nobene substance in da lahko o njenih lastnostih zgolj sklepamo na podlagi pojavov. Na drugi strani lahko Boga, opozarja v natisnjeni različici »Splošne sholije«, spoznavamo po njegovih lastnostih in atributih: "po najmodrejših in najboljših ureditvah stvari in smotrnih vzrokih ter ga občudujemo zaradi popolnosti «.39 Spoštujemo in častimo pa ga zaradi njegovega gospostva, kot njegovi služabniki:

37 Ibid., str. 762-763; slov. prev. str. 77.

38 Besedilo je prevedeno po: A. Rupert Hall in Marie Boas Hall, ur. in prev., Unpublished Scientific Papers of Isaac Newton: A Selection from the Portsmouth Collection in the University Library, Cambridge, Cambridge University Press, Cambridge 1962, str. 356. Gre za rokopis CUL Add. Ms. 3965, 12, fol. 361 ${ }^{\mathrm{r}}$, ki je dostopen tudi na: http://www.newtonproject. ox.ac.uk/view/texts/normalized/NATPooo59.

39 Principia, str. 763; slov. prev. str. 81. 
Bog brez gospostva, previdnosti in smotrnih vzrokov ni nič drugega kot usoda in narava. Iz slepe metafizične nujnosti, ki je nasploh vedno in povsod ista, ne izvira nobena raznolikost stvari. Celotna različnost ustvarjenih stvari glede na mesta in čase je mogla izvirati samo iz idej in volje nujno obstajajočega Bitja. [...] Toliko o Bogu; in razpravljanje o Bogu iz pojavov vsekakor spada na področje filozofije narave..$^{0}$

Tudi v »Splošni sholiji« in njenih osnutkih o spoznavanju teles Newton na bolj nazoren način pove, kar že vemo. Narave teles, njihove substance oz. bistva ne moremo spoznati. O substanci teles imamo toliko ideje kot slepec o barvah: nič. Kar je v tem besedilu z ozirom na Cotesov predgovor in Newtonovo tretje pravilo filozofiranja drugačnega in po mojem prepričanju relevantnega za naše vprašanje, je vpeljava »različnosti ustvarjenih stvari«, ki je posledica ideje in volje Boga. Newton vzpostavlja temeljno razlikovanje med slepo usodo in naključjem na eni strani ter Bogom previdnosti in smotrnih vzrokov na drugi, s posebnim poudarkom na tem, da raznolikost stvari ne more biti posledica »slepe metafizične nujnosti, ki je nasploh vedno in povsod ista«. Newton ima očitno pred seboj vizijo dveh možnih scenarijev, dveh razlag nastanka sveta. Na eni strani je »usoda in narava«, tj. »slepa metafizična nujnost«, iz katere ne more nastati nobena raznolikost, $\mathrm{v}$ čemer z lahkoto prepoznamo mehanicistično idejo narave, po kateri je svet rezultat slepih, naključnih, vedno istih delovanj, na drugi strani je Bog, ki deluje na podlagi svojih idej in volje, ki sledi določenim smotrom in zaradi tega po svoji svobodni volji ustvarja časovno in mestno različnost, kar je Newtonov odgovor na mehanicistično nujnost, za katero meni, da odpravlja Boga. Raznolikost ustvarjenih stvari ne more biti posledica metafizične nujnosti (usode, narave), temveč zgolj in samo »idej in volje nujno obstoječega bitja«.41

Podobno jasen je Newton o izjemni pomembnosti božje volje v besedilu »Tempus et Locus«, ki ravno tako predstavlja enega od osnutkov »Splošne sholije«. Tudi tam zatrjuje, da je raznolikost stvari lahko zgolj in edino posledica umnega dejavnika, ki deluje na podlagi svoje volje:

Karkoli nujno obstaja, obstaja vedno in vsepovsod, saj je zakon nujnosti enak na vseh mestih in v vseh časih. Zato vsa raznolikost stvari, ki jo najdemo na različ-

$40 \quad$ Ibid., str. 763-764; slov. prev. str. 77-78.

${ }_{41}$ Moj poudarek. 
nih mestih in v različnih časih, ni bila nujna, temveč je izvirala iz volje nujno obstoječega Bitja. Kajti samo umno Bitje, ki deluje zaradi smotrnih vzrokov, bi lahko z močjo svoje volje, ustvarilo raznolikost stvari. Raznolikost pa še posebej najdemo na telesih, telesa, ki deluje na čute, so zvezde stalnice, planeti, kometi, Zemlja in njeni deli. ${ }^{42}$

Istovetne ali podobne razmisleke najdemo tudi v nekaterih drugih rokopisih povezanih s Principi. V rokopisu CUL Add. Ms. 3965, fol. 547 ${ }^{\mathrm{r}}$, tako piše: «2 Materija ni večna, temveč ima izvor v volji Boga«, in "3 Človeške duše so nesmrthe, ne zaradi naravnih vzrokov, temveč zaradi božje volje. «43 V istem rokopisu, fol. $542^{\mathrm{r}}$, pa v sicer prečrtanem odlomku obravnava Boga kot substanco in pravi, da substanca,

ki celotna razume, [...] kar se dogaja na njenih posamičnih mestih, [...] katere celotna sila [...] je na delu (viget) na posamičnih mestih, [...] $\downarrow$ ki $\downarrow$ more po svoji volji vse možnosti [oz. potencialnosti] vedno in povsod privesti v dejanskost, $\downarrow \&$ deluje svobodno $\downarrow$, ki ima vse v najboljši meri [...]«.44

Na hrbtni strani istega folija, 542 , pa glede človeške in božje moči ustvarjanja zatrdi, da "moč ustvarjanja gotovo ne more biti večja v Bogu, kot je zmožnost (possibilitas) v ustvarjenih stvareh, zato ker je tista neskončna ta pa samo konč-

42 CUL Add. 3965, 13, fol. 545 $5^{\mathrm{r}}-546^{\mathrm{r}}$ (dopolnjen z 514 ${ }^{\mathrm{r}}-542^{\mathrm{r}}$; Tempus et Locus): »Quicquid necessario existit illud semper et ubique existit, cum eadem sit necessitatis lex in locis et temporibus universis. Et hinc omnis rerum diversitas quae in locis et temporibus diversis reperitur ex necessitate non fuit sed a voluntate entis necessario existentis originem duxit. Solum enim ens intelligens vi voluntatis suae propter causas finales agendo varietatem (rerum) introducere potuit. Varietas autem in corporibus maxime reperitur, et corpora quae in sensus incurrunt sunt Stellae fixae, Planetae, Cometa, Terra, et eorum partes.] Navedeno in prevedeno po: James McGuire, »Newton on Place, Time and God: An Unpublished Source«, British Journal for the History of Science 11 (1978), str. 123.

43 V izvirniku: "2 Materia non est æterna sed originem habuit a voluntate Dei«; "3 Animæ humanæ sunt immortales, non per causas naturales sed per voluntatem Dei.« Cf. http:// cudl.lib.cam.ac.uk/view/MS-ADD-03965/542.

44 Ibid.: »quæ tota intelligit [...] quod in singulis ejus locis agitur, [...] cujus vis [...] tota in singulis locis viget, $[. ..] \downarrow$ quæ $\downarrow$ possibilia omnia semper et ubique pro arbitrio suo in actum deducere potest, $\downarrow \&$ libere agit $\downarrow$ quæ optima omnia $\downarrow$ sunt $\downarrow$ et rationi maxime consentatea [...].« Cf. http://cudl.lib.cam.ac.uk/view/MS-ADD-03965/542. 
na [Kajti božja moč ne seže do stvari, ki so nemogoče (impossibilia)]«. ${ }^{45}$ Enkrat, fol. 496 , celo zapiše, da je Bog svobodno izbral naravne zakone: "Narava je vedno pokorna zakonom, Bog je svobodno izbral [...] in zakone vzpostavil.«46

\section{Narava telesa in Newtonov teološki voluntarizem}

Newton torej verjame, da je raznolikost stvarstva odvisna od božje volje. Raznolikost stvari, dejstvo, da se stvari, med njimi seveda tudi telesa, medsebojno razlikujejo, kar spoznavamo prek njihovih lastnosti (tj. na pojavni ravni) z našimi čuti, je lahko posledica zgolj božjih »idej« in »volje«, to pa z drugimi besedami pomeni, da je lahko zgolj posledica božjega svobodnega stvarjenja, stvarjenja, ki sledi božji volji, ne pa metafizični nujnosti.

Toda kakšno zvezo - če sploh - ima to dejstvo za naše vprašanje? Kako je omejitev človeškega spoznanja na pojavno raven teles, kar izključuje spoznanje bistva, povezana z božjo voljo in stvarjenjem sveta? Na prvi pogled nikakor. Toda, če elemente iz »Splošne sholije« - narava teles, raznolikost stvarstva, stvarjenje sveta in božja volja - beremo v luči nekaterih drugih Newtonovih besedil, v katerih se s temi vprašanji ukvarja nekoliko podrobneje, se odgovor na vprašanje odpira kot na dlani. Ključno ozadje našega problema je Newtonov »totalitarni« teološki voluntarizem, ki ga lahko zasledimo v številnih besedilih, časovno segajočih tako v obdobje pred Matematičnimi principi filozofije narave in po njih. ${ }^{47}$

45 Ibid.: »Certe potentia creandi non major $\downarrow$ esse $\downarrow$ potest in Deo quam possibilitas in creaturis, ideoque aut hæc infinita est aut illa tantum finita. [Nam Dei potentia ad impossibilia non extenditur.]« Cf. http://cudl.lib.cam.ac.uk/view/MS-ADD-03965/542 Ibid, fol. 496' : »Natura legibus $\downarrow$ semper $\downarrow$ obtemperat, Deus libere eligit [...] et leges constituit.«Cf. http://cudl.lib.cam.ac.uk/view/MS-ADD-03965/596. O Newtonovem teološkem voluntarizmu obstajajo številne študije, vendar še daleč ni pojasnjen z vseh vidikov. Cf. npr. Francis Oakley, »Christian Theology and the Newtonian Science: The Rise of the Concept of Laws of Nature«, Church History 30 (1961), str. 433-457; P. M. Heimann, „Voluntarism and Immanence: Conceptions of Nature in Eighteenth-Century Thought «, Journal of the History of Ideas 39 (2/1978), str. 271-283; Edward B. Davis, "Newton's Rejection of the 'Newtonian World View': The Role of Divine Will in Newton's Natural Philosophy", Science and Christian Belief 3 (1/1991), str. 103-117; Betty Jo Teeter Dobbs, The Janus Faces of Genius: The Role of Alchemy in Newton's Thought, Cambridge University Press, Cambridge 1991, str. 110-117. Newtonov teološki voluntarizem je spodbijal Peter Harrison, »Was Newton a Voluntarist?«, v James E. Force in Sarah Hutton (ur.), Newton and Newtonianism, Kluwer, Dordrecht 2004, str. 39-63. Njegovo argumente je uspešno ovrgel John Henry, »Voluntarism and Early Modern Science: A Response to Peter 
Tu bom na kratko povzel samo ključna. Prvo besedilo, ki ga imam v mislih, je rokopis, ki izvira iz zgodnjih 70-ih let, in ga poznamo pod naslovom »O očitnih zakonih narave in procesih v vegetaciji (Of natures obvious laws \& processes in vegetation), drugo je »Hipoteza o svetlobi « (An Hypothesis explaining the Properties of Light), ki jo je Newton poslal Kraljevi družbi leta 1675, in tretje, najpomembnejše, je rokopis »O težkosti« (De gravitatione), v katerem je Newton svoj teološki voluntarizem prvič razvil v polnosti. Kot smo videli, so ta vprašanja Newtona zaposlovala tudi, ko je pisal Matematične principe filozofije narave. Iz obdobja po Principih pa so glede omenjene problematike najbolj povedni nekateri teološki rokopisi in določena »izpraševanja» (quaeries) iz Optike.

Newton v »O očitnih zakonih narave in procesih vegetacije« pojasnjuje, da Bog lahko stori, kar želi, če to le ni logično protislovno. $4^{48}$ Eden od primerov, ki ga navaja, se nanaša na človeško brezmejno sposobnost védenja in zmožnost aktivirati materijo (pri tem ima po mojem mnenju v mislih dejstvo, da lahko ljudje premikamo lastna telesa zgolj z mislijo oz. voljo). ${ }^{49}$ Ker lahko Newton svojo moč védenja in moč aktiviranja materije dojema kot brezmejni brez protislovja, taki

Harrison«, History of Science 40 (2002), str. 63-89. Harrison je - razen nekaterih podrobnosti - sprejel Henryjevo kritiko. Cf. Peter Harrison, „Voluntarism and the Origins of Modern Science: A Reply to John Henry«, History of Science 47 (2009), str. 223-231. Cf. tudi Steffen Ducheyne, The Main Business of Philosophy: Isaac Newton's Natural-Philosophical Methodology, Springer, Dordrecht 2012, str. 235-253. Za bolj splošen pregled Newtonovih religioznih nazorov cf. npr. Rob Iliffe, The Priest of Nature: The Religious Worlds of Isaac Newton, Oxford University Press, Oxford 2017.

48 Cf. Dibner Ms. 1031 B, fol. $4^{\text {v }}$. Tole je relevantni odlomek v originalu: »Of God. what ever I can conceive without a contradiction, either is or may bee made by something that is: I can conceive all my owne powers (knowledge, activating matter etc) without assigning them any limits Therefore such powers either are or may bee made to bee. [...] Arg 2. The world might have been otherwise then it is (because there may be worlds otherwise framed then this) Twas therefore noe necessary but a voluntary \& free determination that it should bee thus. And such a voluntary [cause must bee a God] determination implys a God. If it bee said the world could bee noe otherwise then tis because tis determined by an eternall series of causes, thats to pervert not to answer the 1st proposition: For I meane not that the Earth might have been otherwise notwithstanding the precedent series of causes, but that the whole series of causes might from eterity have beene otherwise here, because they may bee otherwise in other places[.] « Dostopno na: The Chymistry of Isaac Newton, ur. William R. Newman 2006: http://purl.dlib.indiana.edu/iudl/newton/ALCHooo81. Cf. tudi Dobbs, The Janus Faces of Genius, str. 266.

49 Besedilo je samo po sebi sicer precej nedorečeno, vendar takšno branje podpirajo druga besedila, ki jih obravnavam v nadaljevanju. 
moči, trdi, obstajata ali bi lahko obstajali, tj. lahko bi bili ustvarjeni. Po teh začetnih mislih se Newton posveti vprašanju o Boga in njegovem razmerju do sveta, natančneje glede njegovega stvarjenja sveta. Newton pri tem preprosto zatrdi, da bi svet »lahko bil drugače, kot je«, ker obstaja možnost, da so bili svetovi oblikovani/načrtovani (designed) drugače. Svet, »kot je«, torej ni rezultat nujnosti, temveč voljne in svobodne odločitve (voluntary and free determination), ki implicira Boga. Zdi se, da je v tem kratkem razmisleku Newtonova glavna skrb zagotoviti obstoj Boga, kar je po tej argumentaciji odvisno od tega, da zmore Bog ustvariti več različnih svetov.

Drugo besedilo, ki sem ga omenil, »Hipoteza o svetlobi«,50 je za nas zanimivo, ker v njem Newton poudarja, da je zmožnost živih bitij, da gibljejo same sebe, tj. moč samo-gibanja, onstran našega razumevanja, kar poveže $z$ božjo podelitvijo principov gibanj telesom. Ker ne razumemo, kako se živali, vključno z ljudmi, gibljejo, po analogiji tudi ne moremo vedeti, kaj je princip gibanja svetlobe: »Bog, ki je podelil živalim samo-gibanje, ki je onstran našega razumevanja, je nedvomno zmožen, da posadi druge principe gibanja v telesa, ki jih lahko prav tako malo razumemo. ${ }^{51}$

Osnovni motivi obeh besedil in problem nemožnosti spoznanja bistev teles se $\mathrm{v}$ konsistentno celoto zlijejo v najpomembnejšem Newtonovem filozofskem besedilu De gravitatione..$^{2} \mathrm{~V}$ tem besedilu je stvarjenje materije, tj. teles, predstavljeno kot odvisno od božje svobodne volje, kar pomeni, da bi Bog lahko telesa ustvaril tudi drugače, kot jih dejansko je, obenem pa Newton trdi, da tega, kako jih je ustvaril, ne moremo razumeti, tako kot ne moremo razumeti našega gibanja lastnih teles. V De gravitatione se Newton, potem ko je obdelal gibanje in prostor, posveti vprašanju narave telesa in njegove razlike od prostora. Njegov cilj je pokazati, da telo, tj. materija, in razsežnost, tj. prostor, nimata iste nara-

50 Za slov. prev. prve polovice besedila v prevodu Valerije Vendramin cf. Newton, Izbrani spisi I, str. 63-79. Original je prvič izšel v Thomas Birch, The History of the Royal Society, 3 zv., A. Millar in the Strand, London 1757, str. 247-305. Besedilo je dostopno tudi na: http://www. newtonproject.ox.ac.uk/view/texts/normalized/NATPoooo2.

${ }^{51}$ »Hipoteza o svetlobi«, str. 73. O tej problematiki cf. tudi Henry Guerlac, »Theological Voluntarism and Biological Analogies in Newton's Physical Thought", Journal of the History of Ideas 44 (1983), str. 219-229, in Rob Iliffe, " 'That Puzleing Problem': Isaac Newton and the Political Physiology of Self«, Medical History 39 (1995), str. 433-458.

52 Cf. Newton, Izbrani spisi I, prev. Matej Hriberšek in Matjaž Vesel, str. 81-143. 
ve, kot trdi Descartes v Principih filozofije II, 4 in $11 .{ }^{53}$ Vendar pa je v primerjavi z naravo prostora narava telesa mnogo bolj izmuzljiva, bolj negotova oziroma manj zanesljiva, saj »ne obstaja po nujnosti, ampak po božji volji«.54 Prostor je namreč po Newtonu - med drugim - tudi nujni emanativni učinek Boga in afekcija vsega bivajočega: brez prostora ne obstaja nič, tudi sam Bog ne.

Nezanesljivost v razlagi narave telesa je posledica dejstva, da so telesa učinek delovanja božje moči, pri čemer pa nam ni jasno, kakšne so meje, omejitve - in ali sploh kakšne so - delovanja božje moči. Bolj specifično to pomeni, da ne vemo "ali je bilo materijo mogoče ustvariti samo na en način ali obstaja več načinov, na katere je bilo mogoče ustvarjati različne, telesom zelo podobne bivajoče stvari«. ${ }^{55}$ Sicer je res, da je zelo malo verjetno, »da bi lahko Bog ustvaril telesom zelo podobne bivajoče stvari, ki izvajajo vse njihove dejavnosti in kažejo $<$ vse njihove> pojave, pa kljub temu po bistveni in metafizični sestavi ne bi bile telesa « ${ }^{56}$ vendar pa bi bilo trditi nasprotno neumestno. ${ }^{57}$ Bog bi načeloma lahko ustvaril bivajoče stvari (entia), ki bi bila zelo podobna telesom, ki bi delovale kot telesa, katerih rezultat bi bil popolnoma isti pojavni svet, kot rezultira iz delovanja teles, ki pa bi po svoji bistveni in metafizični konstituciji ne bila telesa. Bog bi torej lahko ustvaril bivajočo stvar, ki bi bila videti kot raca, ki bi hodila kot raca in se oglašala kot raca, pa po svojem bistvu in metafizični konstituciji ne bi bila raca. Običajno so taka bitja sicer race, vendar o tem $v$ primeru teles ne moremo biti prepričani. Oziroma, kot pravi Newton, »ker kljub temu še nimam jasnega in razločnega dojemanja (claram ac distinctam perceptionem) te zadeve, si ne bi drznil trditi nasprotno «..$^{8}$ Ker je temu tako, ker bi Bog lahko ustvaril bivajoče stvari, ki bi bila $\mathrm{v}$ vsem podobne telesom, ki bi izvajale vse njihove dejavnosti in izkazovale celoto njihove pojavnosti, pa kljub temu po bistveni in

53 Cf. René Descartes, Principi filozofije, drugi del, 1-44, prev. Matej Hriberšek, Filozofski vestnik 39 (1/2018), str. 39 in 43. Za original cf. Oeuvres de Descartes, VIII-1, ur. C. Adam in P. Tannery, Cerf, Pariz 1905, str. 42 in 46. V nadaljevanju: AT, št. zvezka, del knjige, člen, stran.

54 »O težkosti«, str. 113.

55 Ibid.

56 Ibid.

57 Nekateri interpreti, npr. Martin Tamny, »Newton, Creation, and Perception«, Isis 70 (1/1979), str. 50, so to izpeljavo razumeli v smislu, da Newton začenja z možnostjo, ki pa jo kmalu sprejme kot resničnost, vendar ta interpretacija ob podrobnejšem branju besedila ni vzdržna.

${ }_{58}$ »O težkosti«, str. 113 . 
metafizični sestavi ne bi bile telesa, je nemogoče podati pozitivno teorijo teles, temveč bo, pravi, »raje opisal neko vrsto bivajočih stvari, ki so v vsem podobne telesom, in za katere moramo nujno priznati, da je njihovo ustvarjanje v domeni Boga, in za katere ne moremo z gotovostjo reči, da niso telesa «.59 Newton torej obrne perspektivo. Namesto, da bi izhajal iz tega, kaj telesa so, bo - zgolj! - opisal bivajoče stvari, ki jih Bog zagotovo lahko ustvari in za katere ne moremo z gotovostjo reči, da niso telesa.

V drugem koraku Newton izhaja iz primerjave človeške moči gibanja lastnega telesa po lastni volji, do katere pride na podlagi misli (če hočem premakniti roko, zadošča že misel, in telo, natančneje del telesa, se premakne; enako velja za celo telo) in božje moči. Ker je zmožnost božje misli »neskončno močnejša in hitrejša « od človeške, moramo tudi Bogu pripisati, da lahko po svoji volji giblje katerakoli telesa, in da lahko z dejavnostjo mišljenja ali volje prepreči, »da bi kaka telesa vstopila v neki prostor, opredeljen z gotovimi mejami«. ${ }^{60}$ Tako bi Bog s svojo močjo lahko povzročil, da bi nek omejen prostor nad Zemljo (npr. gora), postal neprehoden za telesa (ne pa za duhove) in bi ustavljal ali odbijal svetlobo in vse, kar bi zadevalo od njega. Ta prostor bi za naše čute, ki jih Newton tu vzpostavlja kot edine razsodnike, imel lastnosti neprehodnosti in ustavljanja ter odbijanja drugih teles (ne pa tudi duhov), za čute bi bil ta zamejeni prostor telo: »zaradi nepredirnosti bi bil [ta prostor] namreč dotakljiv, viden kot temen in obarvan zaradi odboja svetlobe in če bi nanj udarili, bi odmeval«. ${ }^{61}$ Skratka Bog ima nedvomno moč ustvariti telesa iz omejenih delov prostora in jih tudi po svoji volji premikati.

Preostanek drugega koraka, ki iz naše perspektive manj zanimiv, se izteče v ugotovitev, da bi povsod prisotni Bog lahko ustvaril »telesa « (če bi seveda bili lahko prepričani, da so bivajoče stvari, ki jih vidimo tudi metafizično telesa) tako, da določenim območjem prostora, »določenim količinam razsežnosti«, podeli tri pogoje: gibljivost $v$ absolutnem prostoru; medsebojno nepredirnost in odbijanje po določenih zakonih; zmožnost spodbujanja, stimulacije zaznavanja in predstavljanja v duhovih in zmožnost, da jih različni duhovi gibljejo. ${ }^{62}$

\footnotetext{
59 Ibid.

60 Ibid.

61 Ibid. str. 113-115.

${ }^{62}$ Cf. ibid.
} 
Če povzamem. Newton v prvem koraku, ki zadeva stvarjenje »teles«, opozori, da imamo o božji moči, ki je odvisna od njegove volje, lahko samo omejeno spoznanje. Rezultat prvega koraka je negativen: kar zadeva »telesa « ne moremo biti prepričani ali imamo opravka z bivajočimi stvarmi, ki so metafizično in bistveno telesa ali pa so to zgolj in samo popolnoma podobne telesom. Drugi korak vključuje gibanje teh bivajočih stvari, na kar Newton sklepa preko analogije z našim zavedanjem, da lahko naša biološka telesa premikamo zgolj z močjo volje. Ker mi to zmoremo, lahko to stori tudi Bog; še več, Bog lahko naredi te bivajoče stvari tudi nepredirne.

Newton $\mathrm{k}$ temu dodaja šest, bolj ali manj obsežnih pojasnil (tu se omejujem samo na zadnji dve, ki sta relevantni za obravnavo telesa). $\mathrm{V}$ petem pojasnilu Newton razlaga, na podlagi česa je izpeljal svoj opis (sic!) narave telesa. Ta je izhajal iz treh ločenih, a vendar medsebojno povezanih momentov. Prvič, Newton je opis narave telesa izpeljal iz zmožnosti našega gibanja naših lastnih teles. Težave s takšnim pojmovanjem - če so kakšne - izhajajo torej iz te izhodiščne točke. Drugi temelj opisa telesne narave je bil, da je Bog svet ustvaril zgolj in samo $\mathrm{z}$ dejavnostjo volje, tako kot mi samo $\mathrm{z}$ dejavnostjo volje gibljemo svoja telesa. Tretja osnova, na kateri je gradil, pa je bila, da obstaja med človeškimi in božanskimi zmožnostmi obstaja večja analogija, kot so jo doslej opažali filozofi. Zadnja, šesta, in verjetno najpomembnejša pojasnilna točka je, da opisana ideja teles »jasno vključuje ter kar najbolje potrjuje in razlaga poglavitne resnice metafizike«.63 Te so: da Bog obstaja, saj »ne moremo [...] postavljati takšnih teles, ne da bi obenem postavljali, da Bog obstaja «; ${ }^{64}$ da je Bog »telesa v praznem prostoru ustvaril iz niča «; ${ }^{5}$ in da so ta telesa »bivajoče stvari, razločene od ustvarjenih duhov, da pa se kljub temu lahko $\mathrm{z}$ duhovi zedinijo«. ${ }^{66}$

Na naše osnovno vprašanje - zakaj je po Newtonu naše spoznanje teles omejeno na njihovo pojavno raven, spoznanje njihovega bistva pa nemogoče -, je na podlagi tega besedila sedaj mogoče odgovoriti: ker bi Bog lahko ustvaril bivajoče stvari, ki bi bile pojavno popolnoma istovetne telesom, vendar pa »po bistveni in metafizični sestavi ne bi bile telesa«. Vendar pa s tem posledice Newtonovega

\footnotetext{
$63 \quad$ Ibid., str. 121.

64 Ibid.

65 Ibid.

66 Ibid.
} 
teološkega voluntarizma za spoznavanje sveta še niso izčrpane. Podobne razmisleke o stvarjenju sveta in naravi teles najdemo tudi v nekaterih drugih, nekoliko kasnejših Newtonovih besedilih, v katerih obseg epistemoloških teoloških posledic voluntarizma še razširi.

V znamenitem "31. izpraševanju« iz Optike tako Newton trdi, da so bile »vse materialne stvari«, vsa telesa, sestavljena iz trdih in trdnih delcev, ki so bili povezani na različne načine, »v prvem stvarjenju po preudarku umnega dejavnika« (in the first Creation by the Counsel of an intelligent Agent). ${ }^{67}$ Potem ko označi svet za božji sensorium, primerja božjo moč, da »oblikuje in preoblikuje dele vesolja« z močjo »naše volje, da giblje dele naših lastnih teles«. ${ }^{68}$ Sledi ključni pasus:

In ker je prostor neskončno deljiv, materija pa ni nujno $\mathrm{v}$ vseh prostorih, lahko tudi dopustimo, da je Bog zmožen ustvariti delce materije različnih velikosti in oblik, in v različnih (so)razmerjih s prostorom in mogoče različnih gostot in sil, in s tem spreminjati zakone narave, in narediti različne svetove $\mathrm{v}$ različnih delih vesolja. Sam v vsem tem vsaj ne vidim nobenega protislovja. ${ }^{69}$

Bog torej po Newtonu lahko v vesolju ustvari različne svetove, svetove v katerih veljajo različni zakoni narave. In to - če navedek razumem pravilno - istočasno. Medtem ko obstaja v enem delu vesolja svet, v katerem veljajo, recimo, Newtonovi zakoni gibanja, lahko v drugem svetu istega vesolja obstaja svet, $\mathrm{v}$ katerem ti zakoni ne veljajo, temveč veljajo, denimo, Aristotelovi.

Newton teološki voluntarizem z identičnimi osnovnimi premisami, četudi z nekoliko bolj redkimi izpeljavami v smeri epistemoloških posledic za naravni svet in naše spoznanje istega, lahko zasledimo tudi v nekaterih teoloških rokopisih. $\mathrm{V}$ besedilu znanem kot »Irenicum« tako Newton pravi: "Verjeti moramo, da

${ }_{67}$ Opticks: or, a Treatise of the Reflexions, Refractions, Inflexions and Colours of Light, William Innys, London 1730, str. 402. Cf. tudi ibid., str. 400.

68 Ibid., str. 403.

69 Ibid., 403-404. Tu je besedilo v izvirniku: »And since Space is divisible in infinitum, and Matter is not necessarily in all places, it may be also allow'd that God is able to create Particles of Matter of several Sizes and Figures, and in several Proportions to Space, and perhaps of different Densities and Forces, and thereby to vary the Laws of Nature, and make Worlds of several sorts in several Parts of the Universe. At least, I see nothing of Contradiction in all this.« 
obstaja večno-živeči, vseprisotni, vsemogočni, vsevedni nevidni Bog, stvarnik neba in Zemlje in vseh stvari na svetu. Da je [tj. Bog], kar je, po nujnosti narave, in da so vse druge stvari to, kar so, po moči njegove volje. « ${ }^{70} \mathrm{~V}$ »Razlagi druge knjige kraljev« pojasnjuje, da je treba Boga slaviti zaradi njegove vsevednosti, večnosti, neizmernosti, in vsemogočnosti, vendar pa so ti vidiki božje slave, ki so nastali na podlagi »nujnosti Njegove narave«, skoraj onkraj človeškega spoznanja. Namesto tega Newton spodbuja kristjane, da Boga hvalijo zaradi njegove modrosti, moči, dobrote in pravičnosti. To je »življenje in duša« resničnega čaščenja. Tako kot najmodrejši ljudje ne cenijo toliko tega, da jih hvalijo zaradi njihove višine ali rojstva, telesne moči, dobrega spomina ali drugih darov narave, kot zaradi njihovih modrih, dobrih dejanj, ki so rezultati njihove volje, »tako najmodrejše Bitje zahteva, da ga slavimo ne toliko zaradi njegovega bistva kot zavoljo stvarjenja, ohranjanja in vladanja vsem stvarem po njegovi volji in hotenju . $^{71}$

Newtonova voluntaristična teologija - kolikor je relevantna za problem, ki ga skušam rešiti, in z njim povezana vprašanja - uči v kratkem povzetku naslednje. Na spoznanje pojavnih lastnosti oz. kvalitet teles smo omejeni, ker bi Bog na podlagi svoje totalne svobodne volje in neskončne moči lahko ustvaril telesom zelo podobne bivajoče stvari, ki izvajajo vse njihove dejavnosti in kažejo vse njihove pojave, pa kljub temu po bistveni in metafizični sestavi ne bi bile telesa. Še več, Bog je v vsakem trenutku zmožen oblikovati in preoblikovati dele vesolja in tako spreminjati zakone narave ter celo ustvariti različne svetove v različnih delih vesolja.

70 Keynes Ms. 3 (Irenicum, or Ecclesiastical Polyty tending to Peace), str. 35: »We are to believe that there is one ever-living omnipresent omnipotent omniscient invisible God the creator of heaven \& earth \& of all things therein. That He is what he is by the necessity of nature \& that all other things are what they are by the power of his will.« Rokopis je dostopen na: http://www.newtonproject.ox.ac.uk/view/texts/normalized/THEMoooo3.

${ }_{11}$ Yahuda Ms. 21 (Exposition of 2 Kings, 17: 15-16), fol. $2^{\mathrm{r}}$ : »To celebrate God for his eternity immensity omnisciency \& omnipotency is indeed very pious \& the duty of every creature to do it according to capacity, but yet this part of Gods glory, as it - - - - almost transcends the comprehension of man so it springs not from the freedom of Gods will but from the necessity of his nature. And as the wisest of men delight not so much to be commended for their height of birth strength of body, bewty, strong memory, large fantasy, or other such gifts of nature as for their wise good \& great actions the issues of their will so the wisest of beings requires of us to be celebrated not so much for his essence as for his actions, the creating preserving \& governing all things according to his good will \& pleasure.« Rokopis je dostopen na: http://www.newtonproject.ox.ac.uk/view/texts/normalized/THEMooo64. 


\section{Sklep: epistemološki nasledki Newtonovega teološkega voluntarizma}

Kakšne epistemološke nasledke lahko potegnemo iz tega? John Henry, denimo, trdi, da je pri Newtonu voluntaristični poudarek na svobodi božjega delovanja povezan s prepričanjem $\mathrm{v}$ radikalno kontingenco sveta narave, kar se navezuje na prepričanje, da lahko božje stvarjenje razumemo samo a posteriori, tako, da ga preučujemo in izpeljujejo empirično utemeljene sklepe o tem, kaj je dejansko naredil oz. o tem, kakšen svet je ustvaril. ${ }^{72}$

Ne prvi, osnovni ravni, je to trditev, ki ji seveda ni kaj očitati. Radikalna kontingenca ustvarjenega sveta zahteva empirično preučevanje stvarstva, do spoznanja takšnega sveta ne moremo priti a priori. Vendar pa Henry istočasno spregleda enega od bistvenih epistemoloških nasledkov Newtonove eksperimentalne filozofije - omejitev spoznanja na "zunanjost«, na pojavne lastnosti teles, na svet pojavov. Bistva oz. substance teles so nam nedostopna zaradi svobodne volje Boga, ki se lahko nenehno spreminja in bi lahko celo ustvarila bivajoče stvari popolnoma enake telesom, ki pa po svojem bistvu ne bi bila telesa. Newtonov miselni eksperiment iz De gravitatione in ostala besedila, v katerih so identične ideje izražene nekoliko drugače oz. predstavljajo različice podobnih tem, ne izkazujejo samo, kot pravi Alan Gabbey, »neomejenega skepticizma glede možnosti, da bi kadarkoli odkrili naravo stvari ali telesne substance «, ${ }^{73}$ temveč celo več, pozitivno odpravljajo vsako takšno možnost. Teles ni mogoče definirati oziroma, rečeno bolj natančno, telesa je mogoče definirati, vendar zgolj in samo pogojno, v določenem oziru in ne absolutno. Kot pravi Newton sam: „Če bi bile [te bivajoče stvari] telesa, tedaj bi lahko opredelili, da so telesa določene količine razsežnosti, ki jim povsod prisotni Bog podeljuje neke določene pogoje.«14 vendar pa ne moremo biti nikoli z gotovostjo prepričani, da tudi res so. To je po mojem prepričanju tudi razlog, da Newton tudi tedaj, ko navede kakšno definicijo telesa, to vedno zrelativizira. Tako denimo v osnutku tretje izdaje Principov, ko izrecno zapiše definicijo telesa, ne trdi, da je to metafizično resnična definicija, temveč zgolj »splošno sprejeta«: »Definicija II. Telo imenujem vsako gibljivo in dotakljivo stvar, ki se upira stvarem, ki se jo dotikajo, in katere upor, če

72 Henry, »Voluntarism and Early Modern Science«, str. 81.

73 Alan Gabbey, »The Term materia in Newton and in the Newtonian Tradition«, v Delfina Giovannozzi in Marco Veneziani (ur.), Materia: Atti del XIII colloquio internazionale del lessico intellettuale Europeo, Leo S. Olschki, Firence 2011, str. 429.

74 »O težkosti«, str. 115. Moj poudarek. 
je ta zadosti velik, je mogoče čutiti.«75 Isto velja tudi za De gravitatione. Poleg prej navedene pogojne opredelitve telesa, najdemo tudi v tem besedilu izrecno definicijo telesa na začetku besedila: „Definicija 2: Telo je tisto, kar napolnjuje mesto. ${ }^{76}$ Vendar Newton tudi tu hitro pojasni, da njegova definicija zadeva telo »ne kolikor je fizična substanca, obdarjena z zaznavnimi kvalitetami, ampak samo kolikor je nekaj razsežnega, gibljivega in nepredirnega«, se pravi, da telesa ni definiral »na filozofski način, ampak tako, da sem abstrahiral od zaznavnih kvalitet [...] in postavil samo lastnosti, ki so zahtevane za mestno gibanje«.77 Tudi tu imamo torej definicijo telesa, vendar ne definicijo njegovega bistva ali narave, se pravi absolute, temveč definicijo secundum quid, tj. takšno, ki je ustrezna zgolj za obravnavo teles v gibanju.

Newtonova epistemološka pozicija se še jasneje izriše, če jo primerjamo $s$ pozicijo njegovega poglavitnega filozofskega nasprotnika Descartesa. Tudi Descartes namreč zagovarja teologijo, ki se v izhodiščnih premisah ne razlikuje od Newtonove, zato pa toliko bolj v dodatnih, iz česar sledita dve radikalno nasprotni filozofski teologiji in dve radikalno nasprotujoči si epistemologiji. Descartes razlaga Boga in njegovo razmerje do stvarstva v Principih filozofije na več mestih. ${ }^{78} \mathrm{Za}$ nas je relevantno besedilo s konca četrtega dela, kjer obravnava vprašanje, kako pridemo do vednosti o (zunanjih) oblikah, velikostih in gibanjih delcev, ki jih ne moremo zaznati s čuti, in s tem povezane zadeve. Gre za identično vprašanje, kot ga pojasnjuje Cotes v prej obnovljenem delu pregovora

75 CUL Add. Ms. 3965, 13, fol. 437: »Corpus voco rem omnem Mobilem \& tangibilem qua tangentibus resistitur, \& cujus resistentia, si satis magna sit, sentiri potest.« Navedeno po: James E. McGuire, »Body and Void and Newton's De Mundi Systemate: Some New Sources«, v isti, Tradition and Innovation: Newton's Metaphysics of Nature, Kluwer, Dordrecht 1995, str. 115. Članek je bil prvič objavljen v Archive for History of Exact Sciences 3 (3/1966), str. 206-248.

76 »O težkosti«, str. 85 .

77 Ibid.

${ }^{78}$ O tem cf. tudi Edwin Curley, „Certainty: Psychological, Moral, and Metaphysical«, v Stephen Voss (ur.), Essays on the Philosophy and Science of René Descartes, Oxford University Press, Oxford 1993, str. 11-30; Margaret Osler, Divine Will and the Mechanical Philosophy: Gassendi and Descartes on Contingency and Necessity in the Created World, Cambridge University Press, Cambridge 1994, str. 118-170; Roger Ariew, »Descartes's Fable and Scientific Methodology«, Archives internationales d'histoire des sciences 55 (2005), str. 127-138, še posebej str. 137-138; isti, »The New Matter Theory and its Epistemology: Descartes (and Late Scholastics) on Hypotheses and Moral Certainty«, v Jalobeanu in Anstey (ur.), Vanishing Matter and the Laws of Nature, str. 31-46. 
in Newton v »Pravilih filozofiranja«. Tu se osredotočam samo na Descartesove zaključke. ${ }^{79}$ Četudi nam njegova metoda, pravi Descartes, lahko omogoči, da spoznamo, kako so vse stvari v naravi nastale, ne smemo sklepati, da so dejansko nastale na ta način, ${ }^{80}$ in nadaljuje:

Tako kot bi lahko isti veščak izdelal dve uri, ki obe kažeta čas enako dobro in sta na zunaj popolnoma enaki, znotraj pa imata dve popolnoma različni sestavi kolesc, bi lahko najvišji Tvorec stvari, vse tiste stvari, ki jih vidimo, izdelal na več različnih načinov; kar z največjim veseljem dopuščam kot resnično. In menim, da sem dosegel dovolj, če je tisto, kar sem zapisal, takšno, da natančno ustreza vsem naravnim pojavom. ${ }^{81}$

Rečeno $\mathrm{z}$ besedami naslova tega člena: »Kar zadeva stvari, ki jih ne moremo zaznati s čuti, zadošča pojasniti njihovo možno naravo, četudi je lahko njihova dejanska narava drugačna. ${ }^{82}$ Descartes tu trdi, da bi Bog lahko ustvaril isti in enak svet pojavov, tj. svet, ki ga zaznamo, na več različnih načinov: lahko bi naredil isti »zunaj« z različnimi »notranjostmi«, kar je isto, kot če bi rekel, da bi lahko naredil isti pojavni svet na podlagi svetov z različnimi bistvi. Posledica tega je, da lahko kot filozof doseže največ to, da poda ustrezno sliko sveta naravnih pojavov, ne da bi bil pri tem gotov, ali to ustreza tudi »notranji« realnosti narave, njeni metafizični oz. bistveni konstituciji. Vse kar lahko storimo je, da pojasnimo možno, ne pa dejansko naravo stvari.

Do tu se Newton in Descartes bolj ali manj ujemata. Oba sprejemata osnovno premiso in oba prideta do istega splošnega, ne preveč optimističnega epistemološkega sklepa. Njun Bog lahko ustvari isto »zunanjost«/pojavni svet $\mathrm{z}$ več različnimi notranjostmi/bistvi, oz. kot pravi Gabbey v zvezi z Newtonom: »Bog bi lahko svobodno ustvaril popolnoma drugačen meta-fenomenalni svet, ki bi se ujemal z natanko istimi pojavi. « ${ }^{83} \mathrm{~V}$ Descartesovem primeru to pomeni, da so nekatere njegovih razlag, tako pravi sam, »vsaj moralno gotove«, ${ }^{84}$ četudi so

\footnotetext{
79 Cf. Principi filozofije, AT, VIII-1, IV, 203-206, str. 325-328.

8o Cf. ibid., AT, VIII-1, IV, 204, str. 327.

81 Ibid.

82 Ibid.

83 Gabbey, »The Term materia in Newton and in the Newtonian Tradition«, str. 437.

84 Moralna gotovost je po Descartesu tista, ki zadostuje za delovanje v vsakodnevnem življenju.
} 
negotove v razmerju do neskončne božje moči. Kljub temu pa obstajajo nekatere zadeve, tudi »v razmerju do naravnih stvari« ${ }^{85}$ za katere meni, da so več kot le moralno gotove, se pravi, da so absolutno gotove. Do absolutne gotovosti pride, tako Descartes, kadar »verjamemo, da je popolnoma nemogoče, da bi bilo nekaj drugače, kot sodimo, da je« ${ }^{86}$ Absolutno gotovost pa Descartes - in tu se njegova pozicija začne razlikovati od Newtonove - utemeljuje metafizično, natančneje, z najvišjo dobroto Boga in dejstvi, da Bog ni prevarant; da nam je zato podelil zmožnost, da ločujemo resnico in zmoto in da nas ne more voditi v zmoto, če jo le uporabljamo pravilno, tj. kadar kaj dojemamo jasno in razločno. Takšni so matematični dokazi, védenje, da materialne stvari obstajajo, in vse očitno sklepanje o materialnih stvareh, in - pravi Descartes - mogoče celo nekateri njegovi bolj specifični filozofski rezultati, glede na to, da »so bili izpeljani v nepretrgani verigi iz prvih in najenostavnejših principov človeškega védenja «, ${ }^{87}$ se pravi $a$ priori. Četudi Descartes priznava, da bi Bog lahko ustvaril drugačen pojavni svet z različnimi »notranjostmi «, to epistemološko težavo reši tako, da poudari božjo dobroto in na njej utemeljeno gotovost našega spoznanja. Ključna razlika med Descartesovo in Newtonovo teologijo je torej v tem, da je Newton zagovornik teološkega voluntarizma in to v eni njegovih najmočnejših različic, Descartes pa zagovornik teološkega »intelektualizma«. Bog prvega lahko s svojo neomejeno močjo in na podlagi svoje svobodne volje ustvari ali naredi, karkoli želi, če to ne vsebuje logične protislovnosti, Bog drugega pa je pri svojem delovanju omejen s svojo lastno dobroto. Ta nas zato, kar zadeva zaznavanje in dojemanje, kadar imamo jasne in razločne ideje, ne more prevarati, medtem ko nas Newtonov Bog, kot smo videli, lahko prevara. To je razlog, zakaj Newton zato noče - oz. celo ne more - "pozitivno reči, kakšna je telesna narava«, pri čemer po mojem prepričanju zajema dva pomena, ki ju v enem od svojih člankov obravnava Gabbey. Newton noče podati »nobene razlage o naravi teles, ki ne bi bila izražena v pojmih stvarnih in resničnih bistev, ki nastanejo iz stvarnih vzrokov, potrjujejo pa jih zaznavna evidenca ${ }^{88}$ obenem pa izjavlja, da »se noče posvetiti v arbitrarno teoretiziranje o naravi teles«, ali, rečeno drugače, da »si noče izmišljati hipotez o tem vprašanju«. ${ }^{89} \mathrm{Tu}$ leži zadnji razlog za Newtonovo zavrnitev Descartesove hipotetične filozofije narave in usvojitev eksperimentalne.

\footnotetext{
85 Descartes, Principi filozofije, AT, VIII-1, IV, 206, str. 328.

86 Ibid.

87 Ibid.

88 Gabbey, »The Term materia in Newton and in the Newtonian Tradition«, str. 429, op. 15.

89 Ibid.
} 


\section{Literatura}

Ariew, Roger, »Descartes’s Fable and Scientific Methodology«, Archives internationales d'histoire des sciences 55 (2005), str. 127-138

- »The New Matter Theory and its Epistemology: Descartes (and Late Scholastics) on Hypotheses and Moral Certainty«, v Jalobeanu in Anstey (ur.), Vanishing Matter and the Laws of Nature, str. 31-46

Birch, Thomas, The History of the Royal Society, 3 zv., A. Millar in the Strand, London 1757 Cohen, Bernard, »The Review of the First Edition of Newton's Principia in the Acta Eruditorum, with Notes on the other Reviews«, v P. M. Harman in Alan Shapiro (ur.), The Investigation of Difficult Things: Essays on Newton and the History of the Exact Sciences in Honour of D. T. Whiteside, Cambridge University Press, Cambridge 1992, str. 323-354

Curley, Edwin, »Certainty: Psychological, Moral, and Metaphysical«, v Stephen Voss (ur.), Essays on the Philosophy and Science of René Descartes, Oxford University Press, Oxford 1993, str. 11-30

Damerow, Peter, „Space and Matter in Early Modern Science: The Impenetrability of Matter«, v Matthias Schemmel (ur.), Spatial Thinking and External Representation: Towards a Historical Epistemology of Space, Max Planck Institute for the History of Science, Berlin 2016, str. 175-190

Davis, Edward, «Newton's Rejection of the 'Newtonian World View': The Role of Divine Will in Newton’s Natural Philosophy«, Science and Christian Belief 3 (1/1991), str. 103-117

Dempsey, Liam, »Newtonian Idealism: Matter, Perception, and the Divine Will«, The Southern Journal of Philosophy 52 (1/2014), str. 86-112

Descartes, René, Principia philosophiae, v Oeuvres de Descartes, VIII-1, ur. C. Adam in P. Tannery, Cerf, Pariz 1905, str. 1-348

- Principi filozofije, drugi del, 1-44, prev. Matej Hriberšek, v Filozofski vestnik 39 (1/2018), str. 35-65

Dobbs, Betty Jo Teeter, The Janus Faces of Genius: The Role of Alchemy in Newton's Thought, Cambridge University Press, Cambridge 1991

Ducheyne, Steffen, The Main Business of Philosophy: Isaac Newton's Natural-Philosophical Methodology, Springer, Dordrecht 2012

Gabbey, Alan, »The Term materia in Newton and in the Newtonian Tradition«, v Delfina Giovannozzi in Marco Veneziani (ur.), Materia: Atti del XIII colloquio internazionale del lessico intellettuale Europeo, Leo S. Olschki, Firence 2011, str. 423-445

Garber, Daniel, John Henry, Lynn Joy in Alan Gabbey, «New Doctrines of Body and its Powers, Place and Space«, v Daniel Garber in Michael Ayers (ur.), The Cambridge History of Seventeenth Century Philosophy, 1. zv., Cambridge University Press, Cambridge 1998, str. 553-623 
Guerlac, Henry, »Theological Voluntarism and Biological Analogies in Newton's Physical Thought «, Journal of the History of Ideas 44 (1983), str. 219-229

Hall, Rupert, in Marie Boas Hall (ur. in prev.), Unpublished Scientific Papers of Isaac Newton: A Selection from the Portsmouth Collection in the University Library, Cambridge, Cambridge University Press, Cambridge 1962

Harrison, Peter, »Was Newton a Voluntarist?«, v James Force in Sarah Hutton (ur.), Newton and Newtonianism, Kluwer, Dordrecht 2004, str. 39-63

- »Voluntarism and the Origins of Modern Science: A Reply to John Henry«, History of Science 47 (2009), str. 223-231

Heimann, P. M., »Voluntarism and Immanence: Conceptions of Nature in EighteenthCentury Thought «, Journal of the History of Ideas 39 (2/1978), str. 271-283

Henry, John, »Voluntarism and Early Modern Science: A Response to Peter Harrison«, History of Science 40 (2002), str. 63-89

Iliffe, Rob, »'That Puzleing Problem': Isaac Newton and the Political Physiology of Self«, Medical History 39 (1995), str. 433-458

- The Priest of Nature: The Religious Worlds of Isaac Newton, Oxford University Press, Oxford 2017

Jalobeanu, Dana, »Space, Bodies and Geometry: Some Sources of Newton’s Metaphysics «, Zeitsprünge: Forschungen zur frühen Neuzeit 11 (1-2/2007), str. 81-113

- »The Cartesians of the Royal Society: The Debate over Collisions and the Nature of Body (1668-1670)«, v Jalobeanu in Anstey (ur.), Vanishing Matter and the Laws of Nature, str. 103-129

- »The Nature of Body«, v Anstey (ur.), The Oxford Handbook of British Philosophy in the Seventeenth Century, Oxford University Press, Oxford 2013, str. 213-239

Jalobeanu, Dana, in Peter Anstey (ur.), Vanishing Matter and the Laws of Nature: Descartes and Beyond, Routledge, London 2011

Koyré, Alexandre, Newtonian Studies, Chapman in Hall, London 1965

Leibniz, Gottfried, Anti-barbarus physicus, v isti, Die philosophischen Schriften, 7. zv., ur. C. I. Gerhardt, Berlin 1890, str. 337-344

McGuire, James, »Newton on Place, Time and God: An Unpublished Source«, British Journal for the History of Science 11 (1978), str. 114-129

- »Body and Void and Newton's De Mundi Systemate: Some New Sources«, v isti, Tradition and Innovation: Newton's Metaphysics of Nature, Kluwer, Dordrecht 1995, str. 103-150

Newton, Isaac, Philosophiae Naturalis Principia Mathematica, ur. Alexandre Koyré in I. Bernard Cohen s pomočjo Anne Whitman, tretja izdaja Principia iz leta 1726 z različicami besedila iz prvih dveh izdaj, dva zvezka s kontinuirano paginacijo, Harvard University Press, Cambridge 1972

- Opticks: or, a Treatise of the Reflexions, Refractions, Inflexions and Colours of Light, William Innys, London 1730 
- Philosophical Writings, Cambridge University Press, Cambridge 2014.

- Izbrani spisi I, prev. Matej Hriberšek in Valerija Vendramin, Založba ZRC, Ljubljana 2020

- »Hipoteza o svetlobi«, prev. Valerija Vendramin, v Newton, Izbrani spisi I, str. 63-79

- „ „De gravitatione/O težkosti«, prev. Matej Hriberšek in Matjaž Vesel, v Newton, Izbrani spisi I, str. 81-143

- Matematični principi filozofije narave: kratek izbor, prev. Matej Hriberšek, Filozofski vestnik 41 (3/2020), str. 7-77

- CUL Add. Ms. 3965 (rokopisi povezani s Principia)

- Dibner NMAHRB Ms. 1031 B (sinopsis prvih branj alkemijskih del).

- Keynes Ms. 3 (Irenicum, or Ecclesiastical Polyty tending to Peace).

- Yahuda Ms. 21 (Exposition of 2 Kings, 17: 15-16)

Oakley, Francis, »Christian Theology and the Newtonian Science: The Rise of the Concept of Laws of Nature«, Church History 30 (1961), str. 433-457

Osler, Margaret, Divine Will and the Mechanical Philosophy: Gassendi and Descartes on Contingency and Necessity in the Created World, Cambridge University Press, Cambridge 1994

Tamny, Martin, »Newton, Creation, and Perception«, Isis 70 (1/1979), str. 48-58

Vesel, Matjaž, »Newtonova zgodnja dela: narava svetlobe in barv, teorija materije in filozofski obračun z Descartesom«, v Isaac Newton, Izbrani spisi I, str. 167-230 